\title{
What distinguishes a serial entrepreneur?
}

\author{
Ari Hyytinen \\ Bank of Finland and ETLA \\ and \\ Pekka Ilmakunnas \\ Helsinki School of Economics and HECER
}

Discussion Paper No. 111

August 2006

ISSN 1795-0562

HECER - Helsinki Center of Economic Research, P.O. Box 17 (Arkadiankatu 7), FI-00014 University of Helsinki, FINLAND, Tel +358-9-191-28780, Fax +358-9-191-28781,

E-mail info-hecer@helsinki.fi, Internet www.hecer.fi 


\title{
What distinguishes a serial entrepreneur?*
}

\begin{abstract}
We analyze serial entrepreneurship using a unique cross-sectional survey of employees that is for this study linked with longitudinal, register-based employer-employee data. Serial entrepreneurship accounts for nearly $30 \%$ of the transitions from paid employment into entrepreneurship. What make an entrepreneur serial are her aspirations and her ability to go ahead and live by them. Specifically, we document that having worked in the past as an entrepreneur increases both the probability that a person presently in paid employment aspires to again become an entrepreneur and, holding the aspirations constant, the probability of her again becoming an entrepreneur. We also find that an employee with entrepreneurial aspirations is more likely to become an entrepreneur subsequently, than an employee without such aspirations. Finally, holding aspirations constant, working in the public sector and being a union member are inversely related to the likelihood of transiting into entrepreneurship.
\end{abstract}

JEL Classification: J230, J640, L200

Keywords: self-employment, aspirations, serial entrepreneurship, employer-employee data

Ari Hyytinen

Bank of Finland

PO Box 160

FI-00101 Helsinki

FINLAND

e-mail: ari.hyytinen@bof.fi
Pekka Ilmakunnas

Helsinki School of Economics

PO Box 1210

FI-00101 Helsinki

FINLAND

e-mail: pekka.ilmakunnas@hse.fi

* We are thankful to Hannu Tervo and participants at ONS Analysis of Enterprise Microdata Conference (CAED 2005) in Cardiff, at Max Planck Institute of Economics Workshop on Firm Exit and Serial Entrepreneurship in Jena, at CEBR Conference on Entrepreneurship in Copenhagen, as well as at HECER and ETLA for useful comments on earlier versions of this paper. Hyytinen's work for this paper is in part related to a research project on entrepreneurship at ETLA, funded by the National Technology Agency of Finland, Tekes (project 579/31/03 and 10582/25/04). Ilmakunnas is grateful for support from the ProACT research programme of the Ministry of Trade and Industry and Tekes. We are thankful to Satu Nurmi, Juha Honkkila, and Elias Einiö from Statistics Finland for linking the data sets for our use. The data can be accessed on site at the Research Laboratory of the Business Structures unit of Statistics Finland. The views expressed are those of the authors and do not necessarily reflect the views of the Bank of Finland. 
"Serial entrepreneurs thrive on the excitement of starting a business from scratch, taking an idea to market and making it happen" (European Venture Capital Journal, March 2005, Issue 120, p. 2)

\section{$1 \quad$ Introduction}

Part of the process of firm turnover is the same persons entering and exiting entrepreneurship repeatedly. These persons are serial entrepreneurs. Unlike novice or portfolio entrepreneurs, serial entrepreneurs are repeat business starters who in the past have sold or closed down a business which they at least partly ran and owned and who currently run another, possibly new business which they at least partly own. ${ }^{1}$ While estimates of the scale of serial entrepreneurship are relatively scant, the available evidence and anecdotes suggest that it is widespread. In Scotland for example, serial entrepreneurs run nearly $19 \%$ of established businesses (Westhead, Ucbasaran, Wright, and Binks 2005) and in a British sample of independent firms, the corresponding percentage is as high as $25 \%$ (Westhead and Wright 1998). In Germany $18 \%$ of business owners have previously founded a firm that went out of business (Wagner, 2003).

And yet, despite the prevalence of serial entrepreneurs and their potentially important role as the drivers of the dynamics of industries, we know relatively little about the nature and origins of serial entrepreneurship: What makes an entrepreneur serial, i.e. what makes a person who has gained experience as entrepreneur in the past to start again a business of her own? Is it because she aspires more and thrives more "on the excitement of starting a business" than others, as the above quotation suggests? Or is she driven to serial entrepreneurship by her ability to materialize her entrepreneurial aspirations? That is, has she a greater capacity to live by her aspirations and "to make it happen", as the quotation also suggests? The aim of this paper is to address these questions by studying (i) whether individuals who are currently not entrepreneurs but who have past experience as an entrepreneur have more aspirations than others to start a (new) business of their own and (ii) controlling for such aspirations, whether they have a higher probability of actually transiting into entrepreneurship. We thus examine entrepreneurship both in "imagined markets" (aspirations) and "real markets" (actual transitions). ${ }^{2}$ 
The empirical analysis of this paper builds on a unique, individual level data that consist of a large cross-section survey of employed individuals that has for this study been combined with longitudinal, register-based employee/employer data. Our combined data is unique, for it allows us to identify serial entrepreneurs, to measure their (and other individuals') entrepreneurial aspirations at a point in time when they were not entrepreneurs and to observe whether the aspirations materialized subsequently. Three aspects of the combined data make the measurement of these things possible: First, the Finnish Quality of Work Life Survey from 1997 provide us with a proxy of entrepreneurial aspirations for nearly 3000 individuals at a point in time when they were all organizationally employed, i.e. working for someone else. Second, these survey data have been matched to a longitudinal, register-based (employer-employee) data set. The latter is formed from the Employment Statistics, the Business Register, and other data sets on firms from 1988 to 2002 at the Statistics Finland. These longitudinal, register-based data allow us to observe the employment history of the survey respondents. We use the employment histories to identify whether a person had been an entrepreneur in the past, i.e. prior to the date his aspirations were surveyed. Third, the longitudinal, register-based data allow us to observe subsequent transitions into entrepreneurship over the years that followed the survey, i.e., during the follow-up period from the end of 1997 to the end of 2002. This feature of the data allows us to trace in detail whether the aspirations of a person materialized and hence whether she has gone ahead with and lived by them.

Using these unique data we find that serial entrepreneurship is widespread: In our data, it accounts for nearly $30 \%$ of the transitions from paid employment into entrepreneurship. What make an individual with past entrepreneurial experience a serial entrepreneur are both her aspirations and her ability to realize the aspirations. Specifically, we document that having worked in the past as an entrepreneur increases the probability that a person presently in paid employment (i) aspires to again become an entrepreneur and that holding aspirations constant, (ii) such experience increases the probability of a person presently in paid employment again becoming an entrepreneur. These results are robust to controlling for a number of individual and employer characteristics. In the followup period 1997-2002, the transition rate to entrepreneurship is highest among those who both have past experience and current entrepreneurial aspirations: $30 \%$ 
of them make subsequently a transition into entrepreneurship. However, even among those past entrepreneurs who had no aspirations while employed (in 1997), the transition rate is $15 \%$.

These findings complement the earlier research on serial entrepreneurship that has often relied on case analyses or used specific surveys of firms, in which the object of study (i.e., the respondents of the survey) are entrepreneurs already. In a recent paper, Westhead, Ucbasaran, and Wrigth (2005) examine for example differences between novice, serial, and portfolio entrepreneurs using a sample of 354 firms. They document that these groups of entrepreneurs are behaviourally different, at least in certain dimensions. Using similar data, Westhead, Ucbasaran, Wright, and Binks (2005) study whether the entrepreneur and firm characteristics of these groups are different, but found relatively minor differences. Other examples of the types of the data used and results obtained can be found from Wright, Westhead and Sohl (1998), who provide a useful review of the earlier literature. Closer to the kind of data that we are using are longitudinal studies of individuals, where past experience as an entrepreneur has been found to be a significant explanatory variable for the current status as an entrepreneur or for a transition into entrepreneurship (e.g. Carroll and Mosakowski, 1987, Evans and Leighton, 1989, Shane and Khurana, 2003, Henley, 2004). While insightful, none of these prior studies examine how deeply past entrepreneurs aspire to again become entrepreneurs when they are not, nor study the probability at which their aspirations realize.

This paper provides yet another set of findings, as our estimations indicate that entrepreneurial aspirations predict subsequent behaviour: an employee who has entrepreneurial aspirations is more likely to become an entrepreneur subsequently than an employee without such aspirations. A seminal study on entrepreneurial aspirations is Blanchflower, Oswald and Stutzer (2001). Using a large, random sample (cross-section) from over twenty countries, the study finds that there are large differences across countries in their underlying entrepreneurial spirits. However, they cannot link these cross-section data on aspirations to data on future realisations. Thurik and Grilo (2005) conduct a cross-section analysis of the determinants of preference for self-employment and explain actual entrepreneurship by the preference (and other factors). They find that those having a preference for self-employment have an 18\% higher probability of actually being self-employed than others. In a further study, Grilo and Irigoyen (2006) use 
survey data from the EU and US to investigate how demographic variables and perceptions on administrative hurdles and availability of finance affect preference for self-employment and actual self-employment. We compare in a companion paper to this (Hyytinen and Ilmakunnas, 2006) the labour market behaviour of employed individuals that have entrepreneurial aspirations with those having aspirations to switch job. For that paper we had no data on subsequent realizations. There is also a related literature of nascent entrepreneurship (e.g. Reynolds, Carter, Gartner, and Greene, 2004), where individuals who are already in the process of starting their own business are studied. This process can be thought of as an extreme form of aspirations. Rotefoss and Kolvereid (2005) compare the determinants of entrepreneurial aspirations and nascent entrepreneurship, and using the sub-sample of nascent entrepreneurs study the determinants of business founding. However, they do not use aspirations to predict firm founding. Masuda (2006) investigates regional differences in latent entrepreneurship in Japan, distinguishing between those wishing to become selfemployed and those already preparing for self-employment. Again, the aspirations are not connected to realizations. ${ }^{3}$

The only other study that focuses on the materialization of entrepreneurial aspirations is Henley (2005). His analysis uses the British Household Panel Survey that covers years 1998 to 2002 . Using these data, he documents that at least in Britain, those with entrepreneurial aspirations are indeed significantly more likely to have established a start-up after a year, than those without. Henley also reports that successful transitions from aspirations to new business creation are difficult to predict, as only a handful of demographic factors are associated with them. It moreover appears that albeit aspirations predict behaviour, new ventures are sometimes created hastily, as many transitions into entrepreneurship are not preceded by any type of entrepreneurial aspirations. It is interesting to contrast these results to a branch of social psychology based entrepreneurship research, where entrepreneurial intentions and their realisations have been examined (see Krueger et al., 2000). The (mostly qualitative) accounts of this literature suggest that models of intentions are useful in understanding and predicting entrepreneurial activity.

Our results corroborate Henley's finding that entrepreneurial aspirations predict subsequent entry, but show that their predictive ability is far from being perfect: Pseudo $\mathrm{R}^{2}$ of the regression model increases quite a bit once personal, job 
and plant characteristics are included into the model. This finding should be of interest to European policy-makers, who are worried about entrepreneurial aspirations lying dormant. This worry is not completely unwarranted, for millions of Europeans say each year (in a number of regularly conducted surveys) that they would prefer being self-employed to being an employee, that they think frequently about becoming an entrepreneur and that they are keen to start a business of their own. ${ }^{4}$ Our analysis provides some insights into the reasons for why these aspirations lie dormant and thus why entrepreneurial aspirations are widespread but actual transitions rare: We find, for example, that holding aspirations constant, additional predictors of actual transitions (besides being a serial entrepreneur) are working in the public sector and being a union member, which both are inversely related to the likelihood of transition into entrepreneurship. As Finland shares many of the characteristics that Sweden has as a mature welfare state, these micro-level results have also relevance for the recent debate on the role of the welfare state for entrepreneurship (Henrekson, 2005, 2006; Galbraith, 2006, Dore 2006).

The rest of the paper is organized as follows: In the next section we discuss the data and definition of the variables. In section 3 we present the results of our empirical analysis. Section 4 contains a brief summary.

\section{Data and definition of variables}

\section{$2.1 \quad$ Data sources}

Our basic data set is the Quality of Work Life Survey (QWLS) of Statistics Finland from year 1997. ${ }^{5}$ The initial sample for QWLS is derived from a monthly Labour Force Survey (LFS) of Statistics Finland, where a random sample of working age population is selected for a telephone interview. The 1997 QWLS was based on LFS respondents in September and October who were 15-64 old wage and salary earners with normal weekly working time of at least five hours. 3795 individuals were selected for the QWLS sample and invited to participate in a face-to-face interview. Out of this sample 2978 persons, or 79\%, participated (see Lehto and Sutela, 1999).

QWLS includes questions on the personal characteristics and work experience of the respondents, and a large set of questions on perceived working 
conditions. Statistics Finland supplements QWLS with information from the LFS, such as working time and exact labour market status. Supplementary information on the industry and location of the employer, and on the level and field of education of the respondents is from various registers maintained by Statistics Finland. Importantly for our work, QWLS has a question on entrepreneurial aspirations.

The 1997 QWLS is a cross-section. To study actual transitions to entrepreneurship and past entrepreneurial experiences we had it linked with the Finnish Longitudinal Employer-Employee Data (FLEED) data base of Statistics Finland. FLEED is a combination of various registers on individuals and firms. The information on individuals in FLEED is based on Employment Statistics (ES) data base, which includes information on the labor market status of individuals and their background characteristics from different administrative registers. It covers effectively the whole population of Finland, so we can track over time the labor market behavior of the individuals who are in the 1997 QWLS. The FLEED also provides us with data on the characteristics of an individual's employer. ${ }^{6}$

For this study, we match the 1997 QWLS to FLEED data from 1988 to 2002. These linked data allow us both to check whether a person employed in 1997 had entrepreneurial aspirations then and to trace in detail whether she has gone ahead with and lived by the aspirations. We can also check whether the individuals who were in paid employment in the survey year 1997 had been entrepreneurs in the previous years. Although the data set covers in principle the whole population of individuals and plants/firms, there are some slight problems in linking the various data files. For some individuals, no employer can for example be found. There may also be gaps in the data on individuals and firms over time. These incomplete links mean that when information on the employer of a person is used, the number of observations drops. We therefore make in this paper only use of the pieces of information on plants and firms that are included in the 1997 QWLS.

\subsection{Definition of variables}

We construct two dependent variables for this study: One measuring entrepreneurial aspirations in 1997 and the other for transitions into entrepreneurship between 1997-2002. They are described first. We then turn to 
the measurement of serial entrepreneurship and the definitions of the control variables. The precise definitions of all variables are described in Appendix 1.

\section{Measuring entrepreneurial aspirations in 1997}

The 1997 QWLS includes a question "Have you ever thought about starting your own business or becoming self-employed?", with possible answers "no", “occasionally", “often", and "don't know". We exclude missing observations from the empirical analysis and use a binary indicator for the answer "often" as our primary dummy indicator for having entrepreneurial aspirations on-the-job. We denote this variable ASPIRATIONS. The "don't know" category is interpreted to imply that the individual has at least not often thought about entrepreneurship. Besides "pure" aspirations, our aspirations variable may include also nascent entrepreneurs, since we cannot observe whether the individuals have already taken steps to start a business of their own at the time of the survey. We also establish the robustness of our results with respect to an alternative measure, using a binary indicator for thinking about becoming an entrepreneur at least sometimes. The results of this robustness test are reported in more detail below.

Unfortunately, the wording of the question leaves it somewhat open whether the individuals have had entrepreneurial aspirations in the past, but no longer have them, or whether they currently aspire to start a business of their own in the future. This slightly vague wording however works against us, for it reduces the likelihood that ASPIRATIONS can be related to subsequent behaviour: If the respondents in general no longer had such aspirations at the time of the survey, our aspirations variable should not predict future transitions into entrepreneurship.

\section{Measuring transitions into entrepreneurship between 1997-2002}

The other dependent variable of ours is computed using the actual labour market status of those individuals who were organizationally employed while surveyed in 1997 for QWLS. We trace the labour market moves of each individual by the end of 1997 and thereafter in ES and record if and when a switch into entrepreneurship takes place. ${ }^{7}$ We denote this variable TRANSITION. This variable takes a value of one if an individual (i.e., an employee in the 1997 QWLS sample) is observed as an entrepreneur over the period from the end of 1997 to the end of 2002, and is zero otherwise. ${ }^{8}$ 
The measurement of transitions is based on information on whether an individual is coded as a wage and salary earner or as an entrepreneur. This definition is mainly based on whether the individual belongs to the pension system of entrepreneurs and not to that of employees. ${ }^{9}$ We acknowledge that to define and measure entrepreneurship is difficult (especially in surveys), but have no choice but to use as our primary measure the official definition in the register data.

There also is a secondary (but more problematic) way to define entrepreneurship in our data. For this definition we check whether an individual has income that is defined as "entrepreneurial income" (as opposed to wages or salaries) in income taxation. Albeit seemingly intuitive, this method of identifying entrepreneurs is problematic for a number of reasons: One of them is that entrepreneurs who take all (or part) of their income from the firm in the form of capital income, like dividends, have zero (or low) entrepreneurial income. Moreover, unsuccessful entrepreneurs (because of either bad luck or insufficient skills) are not able raise income from their firm. Finally, family members of entrepreneurs should in many cases be classified as self-employed when they are working in the family firm. And yet, it is possible that they do not take income from the firm in the form of "entrepreneurial income". Despite its deficiencies, we have done some sensitivity analysis of our results by using this alternative definition of entrepreneurs.

\section{Measuring serial entrepreneurship}

Since the FLEED data set has information on past (prior to 1997) activities, we can form a dummy SERIAL for those who had been classified as an entrepreneur at least once prior to 1997. This variable refers to past experience as an entrepreneur, i.e., the same individuals starting new firms and switching between these firms (entrepreneurship) and paid employment at least once in 1988-1997. In our empirical set-up it accounts both for potential and actual serial entrepreneurship: Those who switched between entrepreneurship and paid employment more than once in 1988-1997 are already serial entrepreneurs, whereas those who did so only once are potential serial entrepreneurs (i.e., may become such subsequently, during the latter part of our sample period). 
It worth pointing out three potential deficiencies in SERIAL: First, we cannot identify the reason for having switched to paid employment, which means that SERIAL accounts for both forced exit (firm failure) and voluntary cash-out. It however is unlikely that our past entrepreneurs are a group of failures due to lack of entrepreneurial skills, since these individuals most likely would not have aspirations to start anew. If the forced exit has been due to bad luck, having further aspirations is understandable. Second, we can neither identify whether the individuals have several businesses at the same time, i.e. whether they are portfolio entrepreneurs rather than single-firm owners (either in the past or after transition to entrepreneurship). However, since the persons in our sample were in 1997 in paid employment, it is unlikely that they had had a portfolio of firms which they had actively managed and run prior to 1997 but which they had given up by the time of the survey. Third, we cannot observe whether an individual had been an entrepreneur prior to 1988 . While this is a source of measurement error, it is probable that the effect of past experience as an entrepreneur on subsequent labor market behavior diminishes over time and becomes at some point negligible.

Individuals may also move into entrepreneurship gradually by starting a business as a second job and then eventually becoming fully self-employed if the business succeeds. We have an indicator (SIDE_ENTREPRENEUR) for the individuals who were in 1997 gaining experience as entrepreneur or farmer in a second job. However, since the coefficient of this variable is difficult to interpret (and since it may well be correlated with the variables used for explaining transitions into full-time entrepreneurship), we do not include it in the regression models, except to check the robustness of the main results. ${ }^{10}$

\section{Other explanatory variables}

As to control variables, we make use of our earlier work on the determinants of entrepreneurial aspirations (Hyytinen and Ilmakunnas, 2006). Specifically, we construct the following set of regressors for the multivariate analysis (each of these variables is measured in 1997):

The basic personal characteristics include age and age squared (AGE, and AGE2), gender (FEMALE dummy), education (education levels EDUCATION1 to EDUCATION4), fields of education (technical or natural science TECHNICAL, business, law and social science BUSINESS, humanities, health 
care, teaching etc. HUMANITIES, and other fields OTHER), family (MARRIED dummy, CHILDREN for number of children), as well as indicators for the type of the current employment relationship (PARTTIME, TEMPORARY). MANAGER is an indicator for managerial tasks in current job and is included, because managerial position in current job may enhance the likelihood of receiving relevant entrepreneurial training or learning about demand and supply conditions. UNION is an indicator for labour union members.

We include in the model the log of monthly pay (LOG_PAY) and years of firm-specific experience (TENURE). Firms may use wage as a means of lowering the quit rates, while the relationship between tenure and quit intentions (to entrepreneurship) may be negative because of employee heterogeneity even when there is no true negative state dependence in turnover. To control for heterogeneity we include a variable that measures the number of job changes in the last five years (JOB_SWITCHES). Employees, who have switched jobs often in the past (i.e. period to 1997), are likely to be mobile (and may do it also in the future). We also include a measure for varied experience. To that end, we construct an indicator that equals one if the employee has held more than three clearly different occupations (professions) during her working life (until and including 1997). The indicator, which we denote VARIED_EXPERIENCE, equals zero otherwise. ${ }^{11}$

Finally, we have three dummy variables that describe the attitudes and job satisfaction of the individual, i.e., general dissatisfaction with current work, UNSATISFIED, dissatisfaction with superior, SUPERIOR_BAD, and an indicator for considering content most important in work (as opposed to pay), WORK_CONTENT. Job dissatisfaction has been found to correlate with quit rates, and for many entrepreneurs the wish for independent work rather than high earnings is the reason for starting own business. Wright, Robbie, and Ennew (1997) call the former type of entrepreneurs "craftsmen" and the latter type "opportunists".

We have also included characteristics of the firm for which the interviewed employees were working in 1997. One of them is an indicator on working in the public sector, PUBLIC. This variable allows us to examine whether, holding entrepreneurial aspirations constant, the employees of the public sector are less likely than the employees of the private sector to start their own business. The other plant and firm characteristics include indicators for foreign ownership 
(FOREIGN), plant size (size groups PLANT_SIZE_10 to PLANT_SIZE_500), and industry (industry dummies INDUSTRY_i for 12 industries). A priori, there a number of motivations to include these variables: Corporate culture may for example be more (or less) hostile towards within-firm promotions or intrapreneurship (i.e. with-in firm entrepreneurship) in foreign-owned than in domestically owned firms. Foreign-owned firms may also employ different incentive schemes and corporate governance systems, which obviously might affect the propensity of an employee leaving her firm. Opportunities for entrepreneurial learning on-the-job and scope for within-firm career paths may vary with the size of the plant one is working for. Finally, it is well-documented that the propensity to transit into entrepreneurship varies by industry.

As we will explain in more detail shortly, we run two separate regressions, one for ASPIRATIONS and another for TRANSITION. The model for aspirations should include regressors that are related to the desirability of entrepreneurship, whereas the model for transitions should have variables that relate to the feasibility of realizing the aspirations. Most of our explanatory variables, like work experience and "human capital" variables, are included in both models. However, it can be argued that the attitudinal and job satisfaction variables are such that they primarily affect the desire to switch to self-employment and not the opportunities for such a transition. We therefore conjecture that controlling for aspirations, these variables should have no influence on TRANSITION: UNSATISFIED, SUPERIOR_BAD, and WORK_CONTENT are included only in the aspirations model. This exclusion restriction in no way drives our main findings. It nevertheless makes the two equation system of ours recursive and helps us to address the endogeneity of ASPIRATIONS in the transition model (see the robustness tests).

\section{Results}

\subsection{Univariate analysis}

In Table 1 we cross-tabulate past entrepreneurial experiences (SERIAL) and entrepreneurial aspirations. Conditional on having past entrepreneurial experiences the probability of often thinking about again starting own business is over $15 \%$, whereas among those without such past experiences the corresponding 
figure is only half of that, $7 \%$. Of those who have strong aspirations to become entrepreneurs $10 \%(=24 / 230)$ are serial entrepreneurs.

\section{[INSERT TABLE 1 ABOUT HERE]}

Table 2 shows the relationship between SERIAL and TRANSITION (i.e., observed labour market status at the end of 1997 or after). Table 2 suggests that actual transitions into entrepreneurship are relatively rare. Only $3 \%$ of those who were employed in 1997 (87 individuals) transit into entrepreneurship between 1997 and 2002. Entrepreneurial aspirations on-the-job are not as rare, for almost $8 \%$ of the employed have often thought about starting their own business (cf. the last column of Table 1). Conditional on having had experiences as an entrepreneur, the probability of actual transition is almost $17 \%$, whereas without such experience the probability is only $2 \%$. This difference shows that having been an entrepreneur is no guarantee of future entrepreneurship, but the chances are still much higher than for those who never (or at least not in 1988-96) have had an own business. All in all, serial entrepreneurship accounts for nearly $30 \%$

$(=26 / 87)$ of the transitions into entrepreneurship in our individual level data. ${ }^{12}$ This finding supports the view that serial entrepreneurship has an important role in the formation of new firms.

\section{[INSERT TABLE 2 ABOUT HERE]}

In Figure 1 we plot Kaplan-Meier survival functions. They measure survival as a non-entrepreneur, i.e. starting from 1997 the first transition of an individual into entrepreneurship is defined as the failure event. The survival function is shown separately for the different combinations of SERIAL and ASPIRATIONS. The figure confirms our earlier univariate findings, for it shows clearly that although transitions into entrepreneurship are relatively rare, both past experience and aspirations predict them. Among those who have both previous experience and current aspirations, $30 \%$ transit into entrepreneurship by the year 2002 . Survival as a non-entrepreneur is fairly similar among those who have aspirations but no past self-employment experience (12\% transit to entrepreneurship) and those who have past experience, but no strong aspirations (15\% transit to entrepreneurship). 


\subsection{Probit regressions}

\section{Entrepreneurial aspirations}

The event of materialized entrepreneurial aspirations is discrete rather than continuous. To allow for such a qualitative response, we run probit regressions of the form

$$
\operatorname{Pr}\left(\text { ASPIRATIONS }_{i}=1\right)=\Phi\left[\beta_{\text {Asp }} \text { SERIAL }_{i}+X_{i}{ }^{\prime} \gamma\right]
$$

where, $\Phi$ is the cumulative standard normal distribution function, $X_{i}$ is the vector of regressors (and the constant), $\beta_{A s p}$ is the parameter measuring the effect of SERIAL on ASPIRATIONS, and $\gamma$ is the parameter vector associated with the other regressors. The model is estimated by the method of maximum likelihood, and we report average marginal effects and their robust standard errors. The marginal effects are evaluated for each individual and then averaged over the sample (Bartus, 2005). The marginal effects measure the impacts of infinitesimal changes in the continuous variables and discrete changes in the dummy variables. In view of the possibility that the normal probability model is misspecified (or that there is heteroscedasticity), we use standard errors that are based on the robust Huber-White variance-covariance estimator. For a more detailed discussion of the model and these estimators, we refer the reader to Cameron and Trivedi (2005).

Table 3 reports the results of our cross-section probit estimations for having entrepreneurial aspirations in the QWLS in 1997. In the first column we include only SERIAL to see how well the aspirations can be predicted with this variable alone. The average marginal effect is highly significant and indicates that when other factors are not controlled, an employee who has past entrepreneurial experience is $8 \%$ more likely to have entrepreneur aspirations, than an employee without such experience. This coincides well with the cross-tabulation in Table 1. 
In column 2 we add personal and job-related characteristics from the QWLS as regressors. These are the same as in our earlier paper on entrepreneurial aspirations (Hyytinen and Ilmakunnas, 2006). The marginal effect of SERIAL remains significant, but its magnitude drops to 0.06. In column 3 we further add plant and firm characteristics. In this case the magnitude of the marginal effect of SERIAL stays close to that in column 2. To save space, we do not report in the table the marginal effects of the control variables, but note that they are similar to what we report in Hyytinen and Ilmakunnas (2006). For example, based on the model in column 3 of Table 3, we find that females and married persons have fewer aspirations to become an entrepreneur. Those who are unsatisfied with their work and their superior, as well as those who are often experimenting with new ideas at work and who think that content is the most important aspect in work are also more inclined to think about entrepreneurship. Finally, those with varied work experience have a higher probability of having entrepreneurial aspirations.

\section{Transitions into entrepreneurship}

To test how well the indicator for serial entrepreneurship predicts subsequent entrepreneurship, controlling for entrepreneurial aspirations (and other factors), we use the probit model

$$
\operatorname{Pr}\left(\text { TRANSITION }_{i}=1\right)=\Phi\left[\beta_{\text {Trans }} \text { SERIAL }_{i}+\delta \text { ASPIRATIONS }_{i}+X_{i}{ }^{\prime} \pi\right](2)
$$

where $\beta_{\text {Trans }}$ is the parameter measuring the effect of SERIAL on TRANSITION, $\delta$ is the parameter measuring the effect of ASPIRATIONS on TRANSITION, and $\pi$ is the parameter vector associated with the other regressors $X$ (including the constant).

We first use only SERIAL to explain the transitions. Column 1 of Table 4 shows that its average marginal effect is highly significant and indicates that when other factors are not controlled, an employee who has past entrepreneurial experience is almost $15 \%$ more likely to become an entrepreneur subsequently, than an employee without such experience. Again, this is well in line with the cross-tabulation in Table 1. In column 2 we add entrepreneurial aspirations as an explanatory variable. Controlling for aspirations, those who have been entrepreneurs at least once in the previous nine years, but are not entrepreneurs at 
the time of the survey, have almost $13 \%$ higher probability of transiting subsequently into entrepreneurship. This finding provides further support for the view that serial entrepreneurship has an important role in the formation of new firms.

Another finding is that having entrepreneurial aspirations increases the probability of transition by $10 \%$. This positive relation means that transitions to entrepreneurship are on average preceded by entrepreneurial aspirations and that aspirations can be a useful predictor of subsequent labour market behaviour. This result corroborates that of Henley (2005) and is of particular interest, for a typical criticism against using aspirations data in economics is that an individual's aspirations may predict her actual behaviour only poorly, if at all, even if she is unconstrained to live by her aspirations. The finding that entrepreneurial aspirations are positively correlated with the actual transitions into entrepreneurship is of interest also for another reason: Unless the transitions to entrepreneurship are preceded by some kind of search and systematic development of entrepreneurial ideas that the entrepreneurial aspirations reflect, actual transitions into entrepreneurship must be relatively hasty and the potential pool from which the supply of entrepreneurs come, becomes ill-defined.

\section{[INSERT TABLE 4 ABOUT HERE]}

In column 3 we add personal and job-related characteristics as regressors. The variables that we add are the same as in the aspirations models reported above, bar UNSATISFIED, SUPERIOR_BAD, and WORK_CONTENT, which we exclude from the transitions model to make the two equation system recursive (as explained above). The marginal effect of SERIAL stays significant and is close to that in column 2. The marginal effect of ASPIRATIONS drops slightly. In column 4 we add plant and firm characteristics, but this changes the average marginal effects of SERIAL and ASPIRATIONS very little. We find, moreover, that compared to entrepreneurial aspirations, actual transitions to entrepreneurship are more difficult to explain with the observed characteristics of the individuals or of their employer. Further, it seems that the predictive ability of aspirations is however far from being perfect: Pseudo $\mathrm{R}^{2}$ of the regression model increases quite a bit once the remaining personal, job and plant characteristics are included into

the model. To save space, we do not report in the table the marginal effects of the 
control variables. It is nevertheless of interest that, holding aspirations constant, we can observe the following relations:

- Working (in 1997) in public employment reduces the probability of future transition to entrepreneurship by $1.7 \%$. Given that this result is conditional on aspirations being held constant and that the actual transitions are fairly rare, this decrease is an economically significant effect. This finding is of interest to policy-makers, for it provides microlevel support for the view that the welfare states with their large public sectors are not particularly supportive for entrepreneurship (e.g. Henrekson, 2005).

- Being a union member decreases the probability of transition, with a marginal effect that is $1.5 \%$.

- Having varied work experience decreases the probability of transition by $1.4 \%$. Interestingly, this effect is different from the aspirations model, where the variable is positively associated with the probability of having entrepreneurial aspirations (see also Hyytinen and Ilmakunnas, 2006).

\section{Robustness tests}

We have checked the robustness of our results by performing additional estimations:

As out first robustness check we examined the possible endogeneity of ASPIRATIONS in the probit model for TRANSITIONS. Indeed, it is likely that the same unobservable individual effects that lead one to have entrepreneurial aspirations also influence subsequent probability of transiting into entrepreneurship. Our model is recursive, as ASPIRATIONS affect TRANSITION, but not vice versa. To account for endogeneity we can therefore estimate the models for ASPIRATIONS and TRANSITION as a bivariate probit model with maximum likelihood, ignoring the simultaneity (see Greene, 2003). The model is identified by the functional form even without exclusion restrictions (Wilde, 2000), but we nevertheless exclude the attitudinal variables from the TRANSITION equation. The main difference to the ordinary probit estimates was that ASPIRATIONS was not quite significant in the TRANSITIONS model. All the other explanatory variables, including SERIAL, that were significant in the single-equation probit models remained significant in the bivariate model. In 
particular, the marginal effect of SERIAL on the conditional probability of actual transition (conditional on having aspirations) was 0.13 . The estimated correlation coefficient of the errors of the two probit models was only 0.11 with standard error 0.26 . Overall, it seems that endogeneity of ASPIRATIONS is not driving our key findings.

Second, as a robustness check of distributional assumptions we estimated the aspiration and transition models with logit, but the results remained very similar to those given above (results not reported in the table).

Third, we have not used the indicator for secondary entrepreneurship (SIDE_ENTRPRENEUR) in the models above, since it may be correlated with the explanatory variables for transitions to full-time entrepreneurship, making this variable endogenous in the equation. However, to check the robustness of our results we estimated the models with this indicator included (the results are not reported in the table). The results indicate that the average marginal effect of SIDE_ENTREPRENEUR is large, 0.12 (in a model that corresponds to column 4 in Table 4) and significant. Inclusion of the variable does not, however, change our conclusions on the effects of ASPIRATIONS and SERIAL. Moreover, the order of magnitude of their marginal effects does not change. Our conclusions regarding the other variables also remain unchanged.

Fourth, we used longitudinal rather than cross-sectional analysis to study the transitions. We report these results in Appendix 2. The findings from discrete time duration models support our earlier conclusions. Both SERIAL and ASPIRATIONS have a significant positive effect on transitions to entrepreneurship. Since in the longitudinal analysis we examine year-to-year transitions, the marginal effects are, however, smaller: both variables increase the probability of transition (conditional on not having transited earlier) by approximately $2 \%$.

Fifth, we experimented with an alternative aspirations measure, ASPIRATIONS_B, which includes the categories "occasionally" and "often" in the QWLS survey question on the frequency of employees' entrepreneurial aspirations (see Appendix 1 for the precise definition). These results, which are not reported in the table, indicate that when ASPIRATIONS_B is used as the dependent variable, SERIAL has a marginal effect that is negative, but close to zero and clearly insignificant. This finding is natural because there is much less difference between serial entrepreneurs and others that when the definition of 
aspirations is broadened. Also the set of controls with significant marginal effects is somewhat different when ASPIRATIONS_B is used instead of ASPIRATIONS. We further estimated the probit model for TRANSITIONS using ASPIRATIONS_B as an explanatory variable. In this case the average marginal effect of ASPIRATIONS_B was 0.04 and that of SERIAL 0.13 (both significant at $1 \%$ level) in a model that corresponds to column4 in Table 4. Our conclusions on the impact of serial entrepreneurship on actual transitions are therefore not altered when we control for aspirations with the alternative measure.

Finally, we considered the alternative identification of entrepreneurs, based on entrepreneurial income. As could be expected, the number of persons with past entrepreneurial experience decreased. It turned out, in particular, that in several cases those defined as entrepreneurs according to their labour market status had no entrepreneurial income. ${ }^{13}$ Interestingly, we also found that the number of transitions to entrepreneurship increased. The results of the probit models for entrepreneurial aspirations and transitions showed, however, that our main findings are robust to using this alternative measure of entrepreneurship. In particular, the marginal effects of serial entrepreneurship were slightly lower, but still significant.

\section{Conclusions}

Despite the prevalence of serial entrepreneurship and the potentially important role of repeat entrepreneurs as the drivers of the dynamics of corporations and industries, we know relatively little about the nature and origins of serial entrepreneurship. The aim of this paper is to fill this apparent gap in the literature by investigating (i) whether employed individuals who are currently not entrepreneurs but who have past experience as an entrepreneur have more aspirations than others to start a (new) business of their own and (ii) controlling for such aspirations, whether they have a higher probability of actually transiting into entrepreneurship.

This paper takes advantage of the Finnish Quality of Work Life Survey from 1997 that has been matched to longitudinal employer-employee data from 1988 to 2002. Since our aim is to investigate the relation between entrepreneurial aspirations and subsequent realizations, our analysis has focused on a sample of individuals who were in paid employment in 1997. Using the sample we have 
been able to check whether a person employed in 1997 had entrepreneurial aspirations then, and whether she had experience as entrepreneur prior to 1997 , and to trace in detail whether she has gone ahead with and lived by the aspirations after 1997. To obtain a more complete picture of the transitions between different labor market states (entrepreneurship, paid employment, unemployment, out of labor force) in the career of the serial entrepreneurs, we would have to use a larger register data set. However, in this case we could not make use of the data on aspirations in the analysis.

Our econometric analysis of the matched data suggests that what make an entrepreneur serial are both her aspirations and her ability to go ahead and live by them. In particular, we have found that:

- Employees with past experience as an entrepreneur are more likely to have aspirations to start a business of their own than those without such experience.

- Controlling for aspirations, having past experience as entrepreneur increases the probability of actual transition by $12 \%$. In our data, serial entrepreneurs account for as much as $30 \%$ of transitions from paid employment into entrepreneurship.

These findings complement the earlier research on serial entrepreneurship that has often relied on case analyses or used specific surveys of firms, in which the objects of study are entrepreneurs already. Our results derive from a completely new type of individual level data that are essentially based on a random sample of people, who were organizationally employed (i.e., working for someone else) at the point of time their entrepreneurial aspirations were surveyed.

We have also documented that while transitions to entrepreneurship are rare, having entrepreneurial aspirations increases the probability of transition by $10 \%$. A natural next question is, why some do not live by their entrepreneurial aspirations? This paper is able to give a preliminary answer: holding aspirations constant, public sector employees and employees who are union members are less likely to transit into entrepreneurship. While a more complete answer to this intriguing question waits for further research, these micro-econometric results are of interest for they bear on the recent debate on the role of the welfare state for entrepreneurship (Henrekson, 2005, 2006; Galbraith 2006 and Dore 2006). 


\section{References}

Bartus, Tamás, 2005, 'Estimation of marginal effects using margeff', Stata Journal 5, 309-329.

Blanchflower, David G., Oswald, Andrew, and Stutzer, Alois, 2001, 'Latent entrepreneurship across nations', European Economic Review 45, 680-691.

Cameron, A. Colin and Trivedi, Pravin K., 2005, Microeconometrics: Methods and Applications, Cambridge: Cambridge University Press.

Carroll, Glenn R. and Mosakowski, E., 1987, 'The career dynamics of selfemployment', Administrative Sciences Quarterly 32, 570-589.

Dore, Ronald, 2006, 'The entrepreneurial house has many mansions', Industrial and Corporate Change 15, 207 - 213.

Evans, David S. and Leighton, Linda S., 1989, 'Some empirical aspects of entrepreneurship', American Economic Review 79, 519-535.

Galbraith , James K., 2006, 'Some notes on entrepreneurship and welfare state', Industrial and Corporate Change 15, 203-207.

Greene, William H., 2003, Econometric Analysis, $5^{\text {th }}$ ed., Upper Saddle River: Pearson Education.

Grilo, Isabel and Irigoyen, Jesus-Maria, 2006, 'Entrepreneurship in the EU: to wish and not to be', Small Business Economics 26, 305-318.

Henley, Andrew, 2004, 'Self-employment status: The role of state dependence and initial circumstances', Small Business Economics 22, 67-82.

Henley, Andrew, 2005, 'From entrepreneurial aspiration to business start-up: Evidence from British longitudinal data', University of Wales Swansea, School of Business and Economics Working Paper SBE 2005/2.

Henrekson, Magnus, 2005, 'Entrepreneurship: a weak link in the welfare state?', Industrial and Corporate Change 14, 437-467.

Henrekson, Magnus, 2006, 'Entrepreneurship: a weak link in the welfare state: a reply', Industrial and Corporate Change 15, 579-593.

Hyytinen, Ari and Ilmakunnas, Pekka, 2006, 'Entrepreneurial aspirations: Another form of job search?', Small Business Economics, forthcoming.

Krueger, Norris F. Jr., Reilly, Michael D., and Carsrud, Alan L., 2000, 'Competing models of entrepreneurial intentions', Journal of Business Venturing 15, 411-432.

Lazear, Edward P., 2004, 'Balanced skills and entrepreneurship', American Economic Review 94, Papers and Proceedings, 208-211.

Lazear, Edward P., 2005, 'Entrepreneurship', Journal of Labor Economics 23, 649-680.

Lehto, Anna-Maija and Sutela, Hanna, 1999, Efficient, More Efficient, Exhausted. Findings of Finnish Quality of Work Life Surveys 1977 - 1997, Helsinki: Statistics Finland.

Maliranta, Mika and Nurmi, Satu, 2004, 'Analyzing entrepreneurship with the Finnish linked employer-employee data (FLEED)', ETLA Discussion Paper No. 920.

Masuda, Tatsuyoshi, 2006, 'The determinants of latent entrepreneurship in Japan', Small Business Economics 26, 227-240. 
Reynolds, Paul D., Carter, Nancy M., Gartner, William B., and Greene, Patricia G., 2004, 'The prevalence of nascent entrepreneurs in the United States: Evidence from the panel study of entrepreneurial dynamics', Small Business Economics 23, 263-284.

Rotefoss, Beate and Kolvereid, Lars, 2005, 'Aspiring, nascent and fledgling entrepreneurs: An investigation of the business start-up process', Entrepreneurship and Regional Development 17, 109-127.

Shane, Scott and Khurana, Rakesh, 2003, 'Bringing individuals back in: The effects of career experience on new firm founding', Industrial and Corporate Change' 12, 519-543.

Tervo, Hannu, 2004, 'Self-employment dynamics in rural and urban labour markets', paper presented at the 44th European Congress of the International \& European Regional Science Association, August 27-30, 2004, Porto.

Thurik, Roy and Grilo, Isabel, 2005, 'Latent and actual entrepreneurship in Europe and the US: Some recent developments', International Entrepreneurship and Management Journal 1, 419-459.

Van Praag, C. Mirjam and Van Ophem, Hans, 1995, 'Determinants of willingness and opportunity to start as an entrepreneur', Kyklos 48, 513-540.

Wagner, Joachim, 2003, 'Testing Lazear's jack-of-all-trades view of entrepreneurship with German micro data', Applied Economics Letters 10, 687-689.

Wagner, Joachim, 2003, 'Taking a second chance: Entrepreneurial restarters in Germany', Applied Economics Quarterly 49, 255-272.

Westhead, Paul, Ucbasaran, Deniz, Wright, Mike, and Binks, Martin, 2005, 'Novice, serial, and portfolio entrepreneur behaviour and contributions', Small Business Economics 25, 109-132.

Westhead, Paul, Ucbasaran, Deniz, and Wright, Mike, 2005, 'Decisions, actions, and performance: Do novice, serial, and portfolio entrepreneurs differ?', Journal of Small Business Management 43, 393-417.

Westhead, Paul, and Wright, Mike, 1998, 'Novice, serial, and portfolio founders: Are they different?', Journal of Business Venturing 13, 173-204.

Wilde, Joachim, 2000, 'Identification of multiple equation probit models with endogenous dummy regressors', Economics Letters 69, 309-312.

Wright, Mike, Westhead, Paul, and Sohl, Jeff, 1998, 'Editor's introduction: Habitual entrepreneurs and angel investors, Entrepreneurship Theory and Practise 22, Summer 1998, 5-21.

Wright, Mike, Robbie, Ken, and Ennew, Christine, 1997, 'Serial entrepreneurs', British Journal of Management 8, 251-268. 
Table 1: Cross-tabulation of past entrepreneurial experiences and entrepreneurial aspirations

\begin{tabular}{l|llll|l}
\hline $\begin{array}{l}\text { Entrepreneur at } \\
\text { least once in } \\
1988-1996\end{array}$ & \multicolumn{3}{|c|}{ Has thought (in 1997) about starting own business or } & \\
(SERIAL) & "don't know" & "not" & $\begin{array}{c}\text { secoming self-employed } \\
\text { "occasionally" }\end{array}$ & "often" & Total \\
\hline No & 9 & 1761 & 830 & 206 & 2806 \\
& $(0.003)$ & $(0.628)$ & $(0.296)$ & $(0.073)$ & \\
Yes & 4 & 86 & 40 & 24 & 154 \\
& $(0.026)$ & $(0.558)$ & $(0.260)$ & $(0.156)$ & \\
\hline Total & 13 & 1847 & 870 & 230 & 2960 \\
& $(0.004)$ & $(0.624)$ & $(0.294)$ & $(0.078)$ & \\
\hline
\end{tabular}

Note: shares of row totals in parentheses. The original sample is the 1997 QWLS, which includes 2978 employees. We have deleted 7 observations due to missing data on entrepreneurial aspirations, and further 11 observations because of a susceptible labor market status in ES (i.e., having the status of an entrepreneur both in 1996 and 1997). This leaves us with 2960 useable observations.

Table 2: Cross tabulation of past entrepreneurial experience and transition to entrepreneurship

\begin{tabular}{l|ll|l|}
\hline \multirow{2}{*}{$\begin{array}{l}\text { Entrepreneur at least once in } \\
\text { No89-1996 (SERIAL) }\end{array}$} & \multicolumn{2}{|c|}{ Entrepreneur 1997 or } & \\
& after (TRANSITION) & \\
& No & Yes & Total \\
\hline No & 2745 & 61 & 2806 \\
Yes & $(0.978)$ & $(0.022)$ & \\
& 128 & 26 & 154 \\
\hline Total & $(0.831)$ & $(0.169)$ & \\
& 2873 & 87 & 2960 \\
\hline
\end{tabular}

Note: shares of row totals in parentheses. The observations used are the same as in Table 1.

Table 3: Average marginal effects from cross-section probit estimation for entrepreneurial aspirations

\begin{tabular}{|c|c|c|c|}
\hline & $\begin{array}{l}\text { (Model 1) } \\
\text { ASPIRATIONS }\end{array}$ & $\begin{array}{l}\text { (Model 2) } \\
\text { ASPIRATIONS }\end{array}$ & $\begin{array}{l}\text { (Model 3) } \\
\text { ASPIRATIONS }\end{array}$ \\
\hline SERIAL & $\begin{array}{l}0.082 \\
(0.030) * * *\end{array}$ & $\begin{array}{l}0.059 \\
(0.028)^{* *}\end{array}$ & $\begin{array}{l}0.055 \\
(0.027)^{* *}\end{array}$ \\
\hline $\begin{array}{l}\text { Personal and job } \\
\text { characteristics }\end{array}$ & No & Yes & Yes \\
\hline $\begin{array}{l}\text { Plant/firm } \\
\text { characteristics }\end{array}$ & No & No & Yes \\
\hline Pseudo $\mathrm{R}^{2}$ & 0.007 & 0.070 & 0.081 \\
\hline Observations & 2831 & 2831 & 2831 \\
\hline
\end{tabular}

Note: Robust standard errors of average marginal effects in parentheses. $* * *$ significant at $1 \%$ level, $* *$ at $5 \%$ level. The coefficients of personal, job, and plant/firm characteristics not reported. The included variables are listed in the text and Appendix 1. All the estimations make use of the same sample, which is determined by the last model from column 3 of the table. As this model has the largest number of variables and as there are missing observations for some control variables, the estimating sample size is 2831 observations. 
Table 4: Average marginal effects from cross-section probit estimation for transitions to entrepreneurship

\begin{tabular}{l|llll}
\hline & $($ Model 1) & (Model 2) & (Model 3) & (Model 4) \\
& TRANSITION & TRANSITION & TRANSITION & TRANSITION \\
\hline SERIAL & 0.147 & 0.128 & 0.126 & 0.120 \\
& $(0.031)^{* * *}$ & $(0.029)^{* * *}$ & $(0.031)^{* * *}$ & $(0.029)^{* * *}$ \\
ASPIRATIONS & & $\begin{array}{l}0.103 \\
(0.022)^{* * *}\end{array}$ & $\begin{array}{l}0.096 \\
(0.022)^{* * *}\end{array}$ & $\begin{array}{l}0.097 \\
(0.021)^{* * *}\end{array}$ \\
$\begin{array}{l}\text { Personal and job } \\
\text { characteristics }\end{array}$ & No & No & Yes & Yes \\
$\begin{array}{l}\text { Plant/firm } \\
\text { characteristics }\end{array}$ & No & No & No & Yes \\
\hline $\begin{array}{l}\text { Pseudo R } \\
\text { Observations }\end{array}$ & 0.074 & 0.144 & 0.190 & 0.221 \\
\hline
\end{tabular}

Note: Robust standard errors of average marginal effects in parentheses. $* * *$ significant at $1 \%$ level. The coefficients of personal, job, and plant/firm characteristics not reported. The included variables are listed in the text and Appendix 1. (Three attitudinal variables included in Table 3 are excluded.) The observations used are the same as in Table 3.

Figure 1: Kaplan-Meier survival functions

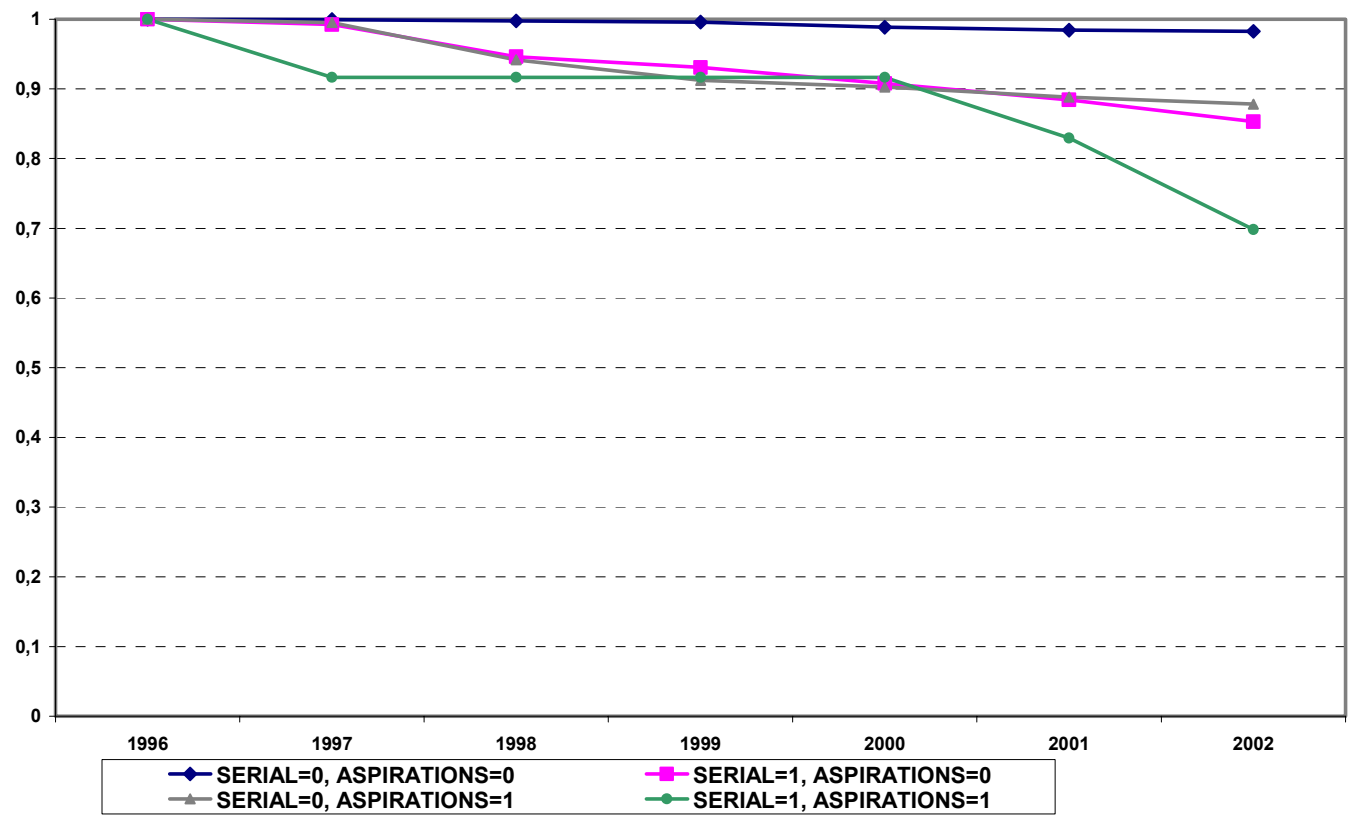




\section{Appendix 1: Description of variables}

In this appendix we report the definitions of our variables in detail.

Entrepreneurship variables

TRANSITION

SERIAL

ASPIRATIONS

ASPIRATIONS_B

SIDE_ENTREPRENEUR

Personal and job characteristics

AGE

AGE2

FEMALE

MARRIED

CHILDREN

EDUCATION1

EDUCATION2

EDUCATION3

EDUCATION4

BUSINESS

HUMANITIES

TECHNICAL

OTHER

UNION

LOG_WAGE
$=1$ if is observed as entrepreneur at least once in 1997-2002; = 0 otherwise (those who were entrepreneurs both in 1996 and 1997 are excluded)

$=1$ if has been classified as entrepreneur at least once in 1988$1996,=0$ otherwise

$=1$ if has thought (in 1997) about starting own business or becoming self-employed "often", = 0 if "occasionally", "not" or "don't know" (missing answers are excluded from the analysis)

$=1$ if has thought (in 1997) about of entrepreneurship or selfemployment "often" or "occasionally", = 0 if "not" or "don't know" (missing answers are excluded from the analysis) $=1$ if has second job as farmer of entrepreneur (in 1997), $=0$ otherwise

age

age squared

$=1$ if female, $=0$ if male

$=1$ if married or cohabiting, $=0$ otherwise

number of children under 18 years living at home

$=1$ if comprehensive education, $=0$ otherwise

$=1$ if upper secondary or vocational education, $=0$ otherwise

$=1$ if polytechnic or lower university degree, $=0$ otherwise

$=1$ if higher university degree, $=0$ otherwise

$=1$, if education in business, law or social sciences, $=0$ otherwise

$=1$ if education in health care, teaching, or humanities, $=0$ otherwise

$=1$ if education in technology, natural sciences or computer science, $=0$ otherwise

$=1$ if education in agriculture and forestry or unspecified field,

$=0$ otherwise (reference group)

$=1$ if member of labour union in 1997, $=0$ otherwise

logarithm of midpoint of self-reported wage interval 
VARIED EXPERIENCE

TENURE

JOB SWITCHES

PARTTIME

TEMPORARY

OVERTIME

EXPERIMENTS

UNSATISFIED

SUPERIOR BAD

WORK_CONTENT

$=1$ if tasks involve supervision of others or delegation of tasks to other employees, $=0$ otherwise

$=1$ if has been in over three distinctly different kinds of occupations during his/her life (up to 1997), $=0$ otherwise

years in current workplace in continuous employment relationship

number of job changes in past 5 years (prior to 1997)

$=1$ if works part time, $=0$ otherwise

$=1$ if in fixed-term employment relationship, $=0$ otherwise

$=1$ if does almost daily overtime for which receives no compensation, $=0$ otherwise

$=1$ if experiments with new things in work continuously or very frequently, $=0$ otherwise

$=1$ if "very dissatisfied" with current job, $=0$ otherwise

$=1$ if very dissatisfied with superior's leadership, $=0$ otherwise

$=1$ if contents are definitely the most important in work, $=0$ otherwise (pay definitely the most important, pay slightly more important than contents, contents slightly more important than pay)

Firm or plant characteristics variables

PUBLIC

FOREIGN

PLANT_SIZE_10

PLANT_SIZE_10-49

PLANT_SIZE_50-499

PLANT_SIZE_500
$=1$ if current employer is state or municipality, $=0$ otherwise

$=1$ if current employer is private, mainly foreign-owned enterprise, $=0$ otherwise

$=1$ if number of persons working in same establishment is under $10,=0$ otherwise

$=1$ if number of persons working in same establishment is 10 $49,=0$ otherwise

$=1$ if number of persons working in same establishment is 50 499, $=0$ otherwise

$=1$ if number of persons working in same establishment is 500 or more,$=0$ otherwise

INDUSTRY i dummies for industries $\mathrm{i}=\mathrm{AB}$ (agriculture, forestry, fishing), CDE (mining, manufacturing, energy), F (construction), G (trade), $\mathrm{H}$ (hotels and restaurants), I (transportation and communications), J (finance), $\mathrm{K}$ (real estate and business services, L (public administration), M (education), $\mathrm{N}$ (health and social services), OPX (other public and private services, households, industry unknown) 


\section{Appendix 2: Longitudinal analysis}

To analyze the impact of various variables on the transitions over time we used discrete time duration analysis. We explain the binary indicator for transiting into entrepreneurship, TRANSITION ${ }_{\mathrm{it}}$. For each individual making a transit the observations up to transition are kept, and for those who do not make a transition, i.e., for whom the duration is right-censored, all the observations in the data period 1997-2002 are kept. (There are some individuals who become entrepreneurs in the data period, but make a transition back to paid employment. For them only the time up to the first transition to entrepreneurship is included.) For the remaining (pooled) data we model the probability that transition happens at time $\mathrm{t}$ given that it has not yet happened:

$$
p_{i t}=\operatorname{Pr}\left(\text {TRANSITION }_{i t}=1 \mid \text { TRANSITION }_{i, t-1}=0, \ldots, \text { TRANSITION }_{i 0}=0\right)
$$

where subscript 0 indicates year 1997 . To model the probability we use the complementary log-log transformation, which yields the discrete time proportional hazards model (see e.g. Cameron and Trivedi, 2005):

$p_{i t}=F\left[\alpha_{t}+\beta_{\text {Trans }} \operatorname{SERIAL}_{i}+\delta \operatorname{SSPIRATIONS}_{i}+X_{i t} \gamma\right]$

where $F()=.1-\exp (-\exp ()$.$) . The intercepts \alpha_{t}$ are allowed to vary over time by including either $\ln (t)$ or a polynomial of time $t$ as a regressor in the model. Note that both ASPIRATIONS and SERIAL are time-invariant, as they measure the status in 1997. Some of the regressors in the vector $X_{i t}$ could be time-varying. However, since in the current work we have used only the variables from QWLS, also $X$ is time-invariant.

The average marginal effects are presented in Table A1. Since the number of transitions in any particular year is small and because most of the regressors are categorical, many of the transitions would be perfectly explained. Further, it is likely that in a longitudinal analysis the variables that relate to characteristics of the employment relationship and workplace in 1997 would not have explanatory power for year-to-year transitions in subsequent years. Therefore we used a restricted set of explanatory variables. It includes only the personal characteristics (age, level and field of education, marital status, number of children, and log of 
wage) and the dummies for working in the public sector and for being a member of labour union. Again, only the marginal effects of our main variables of interest are reported in the table.

\section{[INSERT TABLE A1 ABOUT HERE]}

In column 1 SERIAL and the logarithm of time are the only explanatory variables. Having past experience as entrepreneur increases the likelihood of yearto-year probability of switching to entrepreneurship (conditional on not having done that before) by $2.6 \%$. In column 2 of the table we also add entrepreneurial aspirations (in 1997). Now the average marginal effect of SERIAL drops slightly to 0.02 but ASPIRATIONS increases the likelihood of year-to-year probability of switching to entrepreneurship. Given that the overall year-to-year transition rate is less than $1 \%$, these are relatively large effects. In column 3 , where we have added the other controls, the marginal effects of these two key variables stay about the same as in column 2 . The time variable $\ln (t)$ has a small positive marginal effect. This implies a small trend in the baseline hazard. Among the explanatory variables not reported in the table the only significant marginal effects were those of PUBLIC and UNION. Working in the public sector (in 1997) reduces the yearto-year probability of transition by $0.2 \%$ and being a union member (in 1997) reduces it by $0.3 \%$.

To check the robustness of the results, we estimated the discrete time duration also using logit and probit transformations, but the results differed only little from the proportional hazard results. Instead of using log of time to model the baseline hazard, we also tried a third order polynomial of time, but the coefficients of the time terms were not significant. 
Table A1: Average marginal effects from discrete time proportional hazard duration model

\begin{tabular}{|c|c|c|c|}
\hline & $\begin{array}{l}\text { (Model 1) } \\
\text { TRANSITION }\end{array}$ & $\begin{array}{l}\text { (Model 2) } \\
\text { TRANSITION }\end{array}$ & $\begin{array}{l}\text { (Model 3) } \\
\text { TRANSITION }\end{array}$ \\
\hline \multirow{2}{*}{ SERIAL } & 0.026 & 0.020 & 0.020 \\
\hline & $(0.006)^{* * *}$ & $(0.005)^{* * *}$ & $(0.006)^{* * *}$ \\
\hline \multirow[t]{2}{*}{ ASPIRATIONS } & & 0.017 & 0.015 \\
\hline & & $(0.004)^{* * *}$ & $(0.004)^{* * *}$ \\
\hline \multirow[t]{2}{*}{$\ln (\mathrm{t})$} & 0.001 & 0.001 & 0.002 \\
\hline & $(0.001)$ & $(0.001)^{*}$ & $(0.001)^{* *}$ \\
\hline Personal characteristics & No & No & Yes \\
\hline Wald $\chi^{2}$ & $88.62 * * *$ & $213.39 * * *$ & $282.82 * *$ \\
\hline Observations & 17186 & 17186 & 17186 \\
\hline \multicolumn{4}{|c|}{$\begin{array}{l}\text { Note: Robust standard errors of average marginal effects in parentheses. } * * * \\
\text { significant at } 1 \% \text { level, ** } 5 \% \text { level, } * 10 \% \text { level. The coefficients of personal, } \\
\text { job, and plant/firm characteristics not reported. The included variables are listed in } \\
\text { the main text of this Appendix } 2 \text {. Complementary log-log model is used in } \\
\text { estimation. Wald test statistic tests the joint significance of all coefficients. All the } \\
\text { estimations make use of the same sample, which is determined by the last model } \\
\text { from column } 3 \text { of the table. As this model has the largest number of variables and } \\
\text { as there are missing observations for some control variables, the estimating } \\
\text { sample size is } 17186 \text { observations. }\end{array}$} \\
\hline
\end{tabular}




\section{Notes}

${ }^{1}$ This definition borrows freely from Wright, Westhead and Sohl (1998) and Westhead, Ucbasaran, Wright, and Binks (2005). Serial entrepreneurship need not involve establishing new firms, but can also take the form of e.g. management buyout (see Wright, Robbie, and Ennew, 1997). Another group of "habitual entrepreneurs" are portfolio entrepreneurs. They are individuals who simultaneously manage two or more independent businesses, which they at least party own. In contrast to habitual entrepreneurs, novice entrepreneurs have no prior experience in firm founding.

${ }^{2}$ We owe this terminology to Erik Stam and Roy Thurik.

${ }^{3}$ The cited studies use data on observed entrepreneurial aspirations. In contrast to them, Van Praag and Van Ophem (1995) treat actual transitions to entrepreneurship as a joint realization of two unobservables, willingness and opportunity to start as an entrepreneur.

${ }^{4}$ Examples of such surveys are International Social Survey and Euroflash barometer.

${ }^{5}$ The latest survey is from 2003, but it can not yet be linked to longitudinal data.

${ }^{6}$ For each person in ES a plant (and a firm) appearing in Business Register (BR) is determined as her primary employer during the last week of each year. The BR data base covers registered employers and enterprises subject to VAT. BR can hence be used as a source of data for some firm and plant characteristics, not least because some other firm data sets have been linked to it, too.

${ }^{7}$ In the longitudinal analysis that is reported in Appendix 2 we also take into account the year in which the transition occurs.

${ }^{8}$ The individuals in QWLS should by definition not be entrepreneurs. There are, however, some individuals in QWLS who are coded as entrepreneurs in ES in 1997. Since the information in ES is based on the end of the year situation and the QWLS contains information from a slightly earlier period, it is possible that the individuals have transferred to entrepreneurship after the QWLS survey. The official change of status may also slightly lag the actual transition (see footnote 10 below). To investigate the matter further, we checked whether these individuals were classified as entrepreneurs in 1996. Those who were entrepreneurs both in 1996 and 1997 were then dropped from the analysis, since 
they may have been mistakenly included in the QWLS. Those who were entrepreneurs already in 1997, but not yet in 1996 are included.

${ }^{9}$ See Maliranta and Nurmi (2004) for a discussion on how FLEED can be used for analyzing entrepreneurship. The pension system of entrepreneurs is legislated in SelfEmployed Persons' Pension Act and in Farmers' Pension Act. A self-employed person has to take an insurance under one of these acts if self-employment has lasted for four months after the person reached the age of 18 and if entrepreneurial income exceeds a threshold. The insurance has to be taken within six months from the start of the business. If an individual has wage income at the same time, he/she is defined as an entrepreneur if the entrepreneurial income exceeds the wage income. Some persons have a missing value for their status, but in our data they can, with the help of another variable, be traced to be outside the labour force. Therefore, we have interpreted a missing status to indicate that the individual is not an entrepreneur. This means that transitions to entrepreneurship cover both transitions from paid employment and transitions from outside the labour force.

${ }^{10}$ Note that entrepreneurship as a second job cannot be related to the problem of individuals being coded as entrepreneurs in ES but employees in QWLS. Only one second job entrepreneur is classified as an entrepreneur in 1997.

${ }^{11}$ The measure is similar (but not identical) to what Lazear $(2004,2005)$ and Wagner (2003) use to test the jack-of-all-trades hypothesis.

12 We are not aware of other estimates of serial entrepreneurship for Finland. A comparable number can, however, be derived from the figures reported in Tervo (2004): Making use of a one-percent random sample from the Statistics Finland's Longitudinal Census File, he reports that (i) from 2.1\% (urban areas) to $3.4 \%$ (rural areas) of all individuals transited to self-employment in 1987-1999 at least twice and that (ii) from $9.7 \%$ (urban areas) to $15.8 \%$ (rural areas) of all individuals did it exactly once. Using these numbers we find that close to $18 \%$ of the individuals who transited to selfemployment in 1987-1999 did so at least twice. In our data serial entrepreneurship is 
more common than this alternative estimate suggests. It should be noted, however, that both the definition of repeat entrepreneurship and sample period that underlie this alternative estimate are somewhat different from ours and that Tervo's sample is based on a random sample of the whole population whereas ours is based on a random sample of the employed in 1997.

${ }^{13}$ The decrease may also be due to the possibility that some individuals have become a minority share owner in a company where they previously were the sole or major owner, but for some reason it takes time before their status in the entrepreneurial pension register changes. 